\title{
Trouble and Breakthrough: Realistic Thinking on Career Development of Young Teachers in Colleges and Universities*
}

\author{
Gaohe Wang \\ School of Marxism \\ Jinan University \\ Guangzhou, China 510632
}

\begin{abstract}
The ideal beliefs, moral sentiments, solid knowledge and benevolence are the beacons that guide the career development of young teachers in colleges and universities. Due to various reasons, the current career development of young teachers in colleges and universities faces three major problems: the focus of work should be on teaching or scientific research, the focus of scientific research should be on "quality" or "quantity", and the focus of social services should be on professional advantages or economic interests. To eliminate these problems, we must start from two aspects of young teachers and education departments in colleges and universities, and take the "Four Haves" standard as the guide to create a good environment conducive to the career development of young teachers.
\end{abstract}

Keywords-young teachers in colleges and university; career development; troubles; breakthrough

\section{INTRODUCTION}

The career development of young teachers in colleges and universities is a focus of attention in the education sector in China. In recent years, Li Siya, a young teacher of Sun Yat-sen University, has beaten Professor Gan Yang. Liu Yanjie, a 33-year-old teacher from Chang'an University, died on the way to class. Zhou Ding, a teacher of Sichuan University, published" a statement to make clear one's meaning or position" on the Internet. According to these things, young teachers in colleges and universities have outstanding problems in teaching, scientific research and social services. And it is urgent to solve the problems together with the relevant departments.

\section{THE "Four HAVES" STANDARD IS A BEACON TO GUIDE THE CAREER DEVELOPMENT OF YOUNG TEACHERS IN COLLEGES AND UNIVERSITIES}

On the eve of Teacher's Day in 2014, General Secretary

*Fund Project: This is the key project of the ideological and political special project of Jinan University. "Research on Xi Jinping's theory of ideological and political work in colleges and universities, organic integration of university teachers' career development - Taking Jinan University as an example", the phased results of Jinan University's teaching reform project, "Research on the integration of Xi Jinping's socialism with Chinese characteristics in new era into university teaching."
Xi Jinping put forward the "four haves" criteria for good teachers when discussing with teachers and students of Beijing Normal University: ideals and beliefs, moral sentiments, solid knowledge and benevolence. The "Four Haves" standard is like a beacon, which indicates the direction of the career development of young teachers in colleges and universities.

\section{A. The Ideal Concept Is the Spiritual Pillar of the Career Development of Young Teachers in Colleges and Universities}

Ideal beliefs solve the problem of people's goals and motivations in a certain profession. The accuracy and firmness of ideals and beliefs largely determine the height of a person's professional development. The teacher is a sacred profession, shouldering the glorious mission of teaching and educating people. Whether young teachers in colleges and universities can recognize the loftiness of their profession and establish correct ideals and beliefs directly affects the sense of professional belonging, honor and the space for career development. As General Secretary Xi Jinping said, "The correct ideals and beliefs are the guiding light for teaching and educating people and planting the future. I can't believe the person could be good teachers without a correct ideal and belief" [1]. The fundamental goal of China's higher education is to train qualified builders and reliable successors in the cause of socialism with Chinese characteristics. To achieve this goal, young teachers in colleges and universities must firmly establish communist ideals, strengthen Marxist beliefs, clarify their glorious mission and social responsibility, actively spread the Chinese dream of national prosperity, national rejuvenation and people's happiness, and guide college students to enhance the value identification, affective commitment, cultural identity, and systematic identity. The students would be firm believer and practitioner of socialism with Chinese characteristics.

\section{B. Moral Sentiment Is the Fundamental Foundation for the} Career Development of Young Teachers in Colleges and Universities

The principle of "moral education first, strengthening moral education and cultivating people" is the basic principle 
of higher education. Teachers must not only use their own knowledge to teach people, but also use their own morality to educate people. The young teachers in colleges and universities are not much different from the college students at that age. They have more communication and contact with college students. And their influence on college students' conduct is more direct. Young teachers in colleges and universities should give full play to their above-mentioned characteristics and advantages in personnel training. They must constantly improve moral cultivation, pursue noble sentiments, enhance personality charm, and demonstrate and guide the healthy development of college students. The demonstration role of young teachers' moral sentiments must be carried out through "verbal instruction" and "teaching." As the Chinese educator Ye Shengtao said, teaching by example is the most beautiful. The teaching can't be separated from the knowledge. "Teaching by example" is a model that is enough to be an educated person. Young teachers must hold correct positions in dealing with others, the country and the public. In the right and wrong, good and evil, beauty and ugliness, true and false, straightforward, gains and losses, the teachers can't be vague. They must actively promote and practice the core values of socialism, guide college students to grasp the direction of life. Then, the students would form a correct value orientation, and deduct the "first button" in life.

\section{Solid Knowledge Is an Important Guarantee for the Career Development of Young Teachers in Colleges and Universities}

The Higher Education Law of the People's Republic of China clearly stipulates that cultivating high-level specialized talents with innovative spirit and practical ability is an important task of higher education in China. Senior professional talents refer to the talents with moral, intellectual and physical development. "Morality" is the premise, "intelligence" is the core, and "body" is the foundation. In the process of becoming a senior professional, college students will encounter various problems and confusions in terms of morality, intelligence and body. Especially with the advent of the information age, knowledge update is getting faster and faster. And confusions in thought, profession and life are also increasing. This puts higher demands on teachers' knowledge literacy. "In the past, the teachers should give students a bowl of water. The teacher should have a bucket of water. Now, this requirement is not enough. It should be a pool of water." [1] Due to the short working hours, the accumulation of knowledge and academic accumulation of college young teachers is not enough. Under the new situation, the teachers must play a good role in "preaching, teaching and solving puzzle". The teachers must always be in a rigorous state of learning and hardworking. And they should constantly enrich and improve their own knowledge structure system, strive to stand at the forefront of knowledge development, form a broad vision and solid theoretical foundation, and do extensive learning and "special study".

\section{The Benevolence Is the Source of Motivation for the Career Development of Young Teachers in Colleges and Universities}

Education is the cause filling with the benevolence. Without the benevolence, there is no education. Holding a heart of benevolence is the basic requirement for the education activities of young teachers in colleges and universities. Also, the benevolence would provide the source of motivation for their professional development. "The teachers would educate and love students with the benevolence. Many teachers have the strength to make a class for a lifetime and to dedicate themselves to the threefoot platform for a lifetime. Only doing this can they have the courage to stand up when students are in distress. They would overcome the ignorance of new knowledge and new learning." [1] The benevolence of young teachers is reflected in all aspects of educational activities, the most important of which is to love students. Young teachers should not only internalize their love for students as a kind of concept, but also externalize them into conscious behaviors. They should respect students, understand students, tolerate students, and promote students' healthy growth. On the one hand, the teachers should start from the reality, pay close attention to the students' life and learning status, timely understand the students' emotional changes and psychological confusion, and solve the various practical problems they are experiencing. On the other hand, the teachers should care for the future of students. Young teachers should be good at communicating with students and discovering the endowments, interests and specialties of different students, helping them to tap and develop their potential。And the students gradually become comprehensive persons with individual characteristics, meeting the requirements of the times. In the process of promoting students' healthy growth, young teachers have also developed and achieved a "winwin" situation in teaching and learning.

\section{The Main Problems Faced By the CuRRENT CAREER DEVElopMent OF Young TEACHERS IN COLLEGES AND UNIVERSITIES}

Since the reform and opening up, the soft and hard environment of young teachers in colleges and universities in China has been significantly improved, and a group of young teachers have developed into "four haves" good teachers. At the same time, it should note that new changes in the new situation have also brought new problems to some young college teachers, hindering their professional development.

\section{A. The Problem Whether the Focus of Work Should Be on Teaching or Scientific Research}

Teaching is the most basic way to train talents, and it is the primary responsibility of college teachers. Scientific research is an important way to train talents, and it is an indispensable task for college teachers. Teaching and research are mutually reinforced and complement each other. College teachers should handle the relationship between teaching and research, and make overall plans. However, the current college teacher evaluation mechanism has a tendency to focus on scientific research and lighting teaching. Just as 
Zhang Yaoxue said, the president of the Central South University, "The university is the first place to teach and educate people. Now everyone has a misunderstanding about the positioning of the university. That is to say, too much emphasis is on innovation results and creating the first-class number of papers, etc. It is easy to ignore students." [2] The colleges and universities would focus on scientific research and lighting teaching. It is mainly reflected in three aspects. First is the title evaluation. The evaluation of professional titles in colleges and universities puts forward the conditions in teaching and scientific research. However, the scientific research is far greater than the teaching in practice. Taking the "Associate Professor of Guangdong Provincial Professional and Technical Qualifications in 2015 as an example", the research requirements mainly include: in the subject, as the main participants, the teachers should participate in the research projects at the city (office) level or above; The colleges and universities would put forward different requirements according to different amounts of the average annual teaching. Those who teach at an average of 320 or above, $240-319,120-239,60-119$, and 59 or less, should publish $5,6,7,8$, and 10 papers respectively. It can be seen that the requirements for scientific research results are clear and specific. It is easy to grasp. More and less, it would be clear. The promotion of professional titles is limited, and the competitive incentives have greatly improved the actual standards of scientific research. Every year, many teachers are "recorded" in scientific research. Teaching requirements require that colleges and universities should comprehensively evaluate the teaching ability, teaching level and teaching effects of the teachers who have applied for the teaching series, and give clear and specific evaluation results." [3] The institution of professional title evaluation does not pay much attention to teaching. However, compared with scientific research, teaching has its own characteristics. There are many hidden values, which are difficult to quantify. Some colleges and universities put the column of "teaching status" to the teachers who participated in the title evaluation. Some colleges and universities use the results of student evaluation as the standard of teaching evaluation. As long as the students' evaluation scores are not within $10 \%$ of the college rank, they can successfully participate in the title evaluation. Few teachers are "recorded" in teaching. The second is funding incentives. Funding rewards are affirmation of the teachers' work, which guides teachers how to allocate working hours. As far as the current situation is concerned, the fund reward mechanism of colleges and universities in China is obviously more focused on scientific research. For example, a key university in the Yangtze River Delta region has a maximum reward of $300,000,120,000$ and 80,000 yuan for national-level major projects, key projects and general projects approved by the project. The papers are divided into four categories according to different reference sources, and articles published in A-level journals are rewarded with more than 100,000 yuan. However, the college lacks detailed teaching incentives, and most teachers' teaching work is not funded. The third is social evaluation. College teachers may receive a variety of honorary titles in their lifetimes. Nationally, there are experts from the State Council with special contributions, national outstanding teachers, Changjiang scholars, 10,000person programs, and outstanding key teachers in national universities. Provincially, there are scholars such as Guangdong Pearl River Scholars, South Guangdong outstanding teachers, Guangdong special-support plan candidates. To turn these honorary titles into the reality, the teachers must make outstanding achievements in scientific research. The colleges focus on scientific research and light teaching, which has negative impact on young teachers. And they are facing with the dilemma of focusing their work on teaching or research. Some young teachers "understand the time" and focus their attention on scientific research. And the teaching becomes a "poor thing". There are also some young teachers who focus their efforts on teaching. However, they have grievances in their hearts that would affect the teaching effect.

\section{B. The Problem Whether the Focus of Scientific Research Should Be on "Quality" or "Quantity"}

Different from re-transmission of knowledge and lighting scientific research and innovation in the traditional university, modern colleges must pay attention to imparting knowledge, producing knowledge, developing knowledge, and realizing scientific research and innovation. Scientific research and innovation is not only the inevitable requirement for promoting the development of colleges and universities, but also the main way to improve the level of young teachers. If colleges do not have their own unique things, and teachers lack their own innovative content, it is difficult to cultivate outstanding talents. In recent years, colleges and universities have paid more and more attention to scientific research and innovation. As the main force of scientific research and innovation, the status of college teachers has become increasingly obvious. However, there are still many problems in the scientific research and innovation system of colleges and universities. In particular, the evaluation of scientific research results has failed to deal with the relationship between "quality" and "quantity". And it has triggered a series of problems. First, it is anxious to achieve quick success and get instant benefits. And it focuses "quantity" and lights "quality". Professional title evaluation, job evaluation and grant awards are directly linked to research results. Under the consideration of "quality" and "quantity" in scientific research work, some young teachers are anxious to achieve quick success and get instant benefits, and put "quantity" before "quality". The innovative highlevel research cycle is long, the investment is large, and the effect is slow. And the repetitive low-level research cycle is short, the investment is small, and the effect is obvious. In the short term, teachers who are eager to innovate in highlevel research may suffer losses in terms of professional title evaluation, job evaluation and funding incentives. The existing academic system has spawned repetitive low-level study. According to relevant statistics, the total number of papers published by science and technology personnel in China surpassed the United States in 2007, ranking first in the world. However, the quality is very different from that of developed countries in Europe and America. The second is to publish research results with establishing a relationship and find intermediary agent. At present, the domestic 
academic evaluation system generally equates the quality of the paper with the level of the publication. Papers published in high-level publications are good papers, and the value of papers published in general journals is common. Domestic universities have different definitions of publications. However, most of them are based on SCI (Science Citation Index), SSCI (Social Science Citation Index), CSSCI (Chinese Social Science Citation Index), and National Chinese Core Journals. There are few types of high-level publications and limited editions. And there are many teachers who expect to publish articles in high-level publications, presenting a situation of "not meeting the needs". Most young teachers have limited connections in the academic circle. In order to publish their papers in high-level publications, they would try their best to establish the relationship with the publication. It is okay to find an intermediary, and they will not hesitate to pay high price. Some lawless persons seized the psychology of college teachers eager to publish papers and defrauded them in the name of intermediaries, causing many young teachers to be deceived. Third, the driving force of scientific research work is not from interest and responsibility, but from external pressure. Interest and responsibility are the internal driving force for research work. If a scientific researcher lacks interest and responsibility for his own research field, it is difficult to achieve the realm of "the bench must be ten years cold." Scientific research will become painful thing, and it is naturally difficult to create high-level results. At present, many college teachers in China conduct scientific research not from interest, but from external pressures such as professional title evaluation and job evaluation. This leads them to choose their research field. They often don't give priority to their own advantages, but to study the difficulty of publishing results. This kind of research method is difficult to sustain. They usually make surprises before professional title evaluation to make up for the number of articles. After the promotion of the title, they suddenly break down. In particular, after some teachers commented on the professors, the scientific research work completely "ended", resulting in a huge waste of intellectual resources in colleges and universities.

\section{The Problem Whether the Focus of Social Service Should Be on the Professional Advantage or the Economic Interest}

Social services are an important function of colleges and universities. With the rapid development of the economy, society has put forward higher requirements for the scope and content of university services. In addition to completing routine teaching and research tasks, college teachers must actively step out of the "ivory tower". And they would provide regular services for social development in the form of education and training, decision-making consultation, and technology transfer. Young teachers occupy half of the faculty of colleges and universities, and they should become an important force in the social service of colleges and universities. However, the current status of social services for young teachers is not ideal. First, the awareness of social services is weak. Social services are not only to meet the needs of economic and social development, but also an important means to promote the professional development of young teachers. Some young teachers are not fully aware of the importance of social services, and regard social services as a matter of being professors and well-known scholars. They believe that it has little to do with themselves. The misunderstanding has led many young teachers not to directly provide social services. And it is impossible to promote professional development with social services. Second, there are fewer ways of social services. Young teachers often provide social services through education and training. The role of providing decision-making consultation for the government, providing technical advice and transferring results for enterprises has not been fully realized. In addition, young teachers are mostly engaged in individual service when they provide social services. They lack a platform for unified guidance and coordination. The strength of young teachers to serve the society has not been effectively integrated. Third, the combination of social services and professional expertise is not strong. Young college teachers have low incomes and unsatisfactory economic conditions, especially after they married. Economic pressure has led some young teachers to give priority to economic interests when choosing social service methods. Professional advantages have been placed in secondary positions. It is often the case that young teachers' services to the society are not related to their professional advantages. This kind of social service has an effect on improving the living conditions of young teachers. And it does not help their career development.

\section{BASIC STRATEGIES FOR YOUNG COLLEGE TEACHERS TO STEP OUT OF THE CAREER DEVELOPMENT PROBLEM}

The problems of the career development of young teachers in colleges and universities are not only related to factors of young teachers, but also related to some policies of the education sector. Therefore, in order to eliminate these problems, we must start from the two aspects of young teachers and the education sector, and take the "four haves" standard as the guide to create a good environment for the career development of young teachers.

\section{A. Young Teachers in Colleges and Universities Should Create a Good Internal Environment for Their \\ Professional Development}

Compared with other professions, young college teachers have higher requirements for themselves. They should consciously use the "four haves" standard to control their own inner world, correct cognitive biases in time, and remove the inherent obstacles affecting career development.

First, the college teachers should strengthen professional ethics education and improve professional accomplishment. The teacher's professional ethics standard gives a clear answer to a series of questions about what a teacher should do and how to do it. It is the guidance for teacher's words and deeds. At present, some college young teachers are confused in dealing with the relationship among teaching, scientific research and social services. Their sense of belonging and honor are not strong. And impetuous psychology increases. To a large extent, their understanding 
of teachers' professional ethics is biased. And they are not clear about what to do and how to do it. Most of the college teachers in China are not graduated from normal colleges and universities, and lack systematic education of teachers' professional ethics. Many young teachers first contact the relevant materials such as "Higher Pedagogy", "Teachers' Professional Ethics of Higher Vocational Schools", "Introduction to Higher Education Law", and "Higher Education Psychology" in the pre-post training of teachers in institutions of higher learning. However, the study time is short (usually a week or so). The learning process is like "a dragonfly skimming the surface of the water". And the effect is not ideal. The understanding of teachers' professional ethics is unclear. And they can't completely tell eight main components of teacher professional ethics (vocational ideals, professional responsibilities, professional attitude, professional discipline, professional skills, professional conscience, professional style and professional honor). Their understanding of teachers' professional ethics mainly comes from self-perception, which will inevitably lead to cognitive bias and cause problems on issues that should not be problematic. To solve this problem, young college teachers must consciously strengthen professional ethics education, systematically study the "Teachers Law of the Peoples Republic of China", "Higher Education Law of People's Republic of China" and other laws and regulations, and accurately understand the teacher's professional ethics. In the annual teacher's ethics education activities held each year; young teachers must "overhaul" their own professional ethics, and improve their cognitive ability to distinguish their career development. It should correctly treat the income and development challenges of young teachers. The young teachers should love students and love education.

Second, the teachers should strengthen mental health education and improve self-adjustment ability. To a certain extent, the process of teaching and educating people is the process in which teachers guide and intervene in the psychological activities of students. Teachers must play the role to promote the mental health of students. The teachers should first be mentally healthy persons. In recent years, colleges and universities have paid more and more attention to the mental health problems of college students. Basically, every college has set up a psychological counseling room for college students. However, there is not enough attention to the mental health of young college teachers in colleges and universities. This is incompatible with the increasing mental health problems of college teachers. Some young teachers have serious problems in their mental health. Their outstanding performance is that they cannot hold objective attitudes towards social reality. It is difficult to accurately assess their own abilities and expectations. Their ability to adapt to changes in the external environment is insufficient. The interpersonal relationships are not harmonious enough, and pessimistic negative emotions increase. These mental health problems not only directly affect the career development of young teachers in colleges and universities, but also have negative impact on the healthy growth of college students. They bring their negative attitudes and emotions into the teaching process. And with these behaviors, it would turn college students into complaints. The college teachers would tell college students about the frustrations in their work and life, vent their dissatisfaction with society, exaggerate the darkness of society, and mislead college students. To eliminate the mental health problems of young teachers in colleges and universities, it is necessary to take measures from many aspects. Young teachers in colleges and universities should strengthen mental health education, systematically study the theory of higher education psychology, master the necessary knowledge of mental health education, and correctly understand themselves and accept themselves, dialectically view problems in social development, scientifically analyze setbacks in work and life, improve self-regulation and adaptability, rationally control emotions, establish harmonious interpersonal relationships, and create a good internal environment for the smooth development of careers. This is very important.

\section{B. The Education Department Should Create a Good External Environment for the Career Development of Young Teachers in Colleges and Universities}

In view of the current problems of the career development of young teachers in colleges and universities, the education department should adjust and improve related policies with the guidance of "four haves", and create a good external environment for the career development of young teachers in colleges and universities.

First of all, the teachers should coordinate the relationship between teaching and scientific research. And it should enhance the enthusiasm of young teachers in colleges and universities. Teaching and research are the two main tasks undertaken by college teachers. They complement each other and are inseparable. The tendency of colleges focusing on scientific research and lighting teaching has damped the enthusiasm of young teachers in colleges and universities. The practical measures should be taken to make the importance of teaching stand out. The first is to increase the proportion of teaching allowances. Young teachers are the main force of teaching work. They have a lot of work and class hours. However, the salary is not high. And the income of young teachers is low. To mobilize the enthusiasm of young teachers, it is imperative to increase the proportion of teaching allowances. The practice of Central South University in the allocation of teaching allowances serves as a reference for other colleges. Central South University allocates $90 \%$ of its performance funds to teaching posts. The income of teachers engaged in teaching work has increased significantly. Some teachers have annual rewards of 200,000-300,000 yuan. This will help teachers teach with peaceful mind and ensure the quality of teaching. The second is to increase the incentives for teaching funding. At present, the scope of college teaching subsidies is narrow and the amount is small. All colleges and universities should revise and improve the teaching subsidy method, expand the scope of subsidy and increase the amount of subsidy, especially for young teachers. More reward programs are set for young teachers who have outstanding performance in teaching, such as the Young Teachers' Teaching Excellence Award, the Outstanding Young Teacher Award, and the most popular Young Teacher Awards. It would enhance their 
sense of accomplishment and honor. Funding support programs are set for young teachers whose teaching level is not high temporarily. The teachers will be encouraged to carry out research on teaching issues, improve teaching methods and teaching ability. And the overall level of teaching of young teachers will be improved. The third is to increase the weight of teaching in the evaluation of professional titles. When formulating the title evaluation policy, the education department should further improve the weight of teaching and enhance the operability of the teaching quality assessment method. For teachers with outstanding teaching achievements, the colleges should set up teaching-type associate professors and professor positions, and give them a special channel for promotion of professional titles. The colleges should strongly support teachers to put more energy into teaching work. Then, it would ensure the central position of teaching work in colleges and universities.

Secondly, the teachers should rationalize the relationship between the quality and quantity of scientific research results. And the colleges should guide young college teachers to concentrate on the creation of fine products. To deal with the relationship between quality and quantity of scientific research results is a problem faced by many young teachers in colleges and universities. In fact, the "Opinions of the Ministry of Education on Further Improving the Evaluation of Philosophy and Social Science Research in Higher Education Institutions" issued in 2011 has already carried out clear answer to this issue. It emphasizes that the evaluation of scientific research results should establish the orientation of quality first. It shouldn't be heroes in terms of the number of papers. Instead, the "innovation and quality guide should be through all aspects and levels of scientific research evaluation. It should fundamentally change the simple evaluation way of talents with the number of results and the practice of evaluating performance." [4] However, it is still a long way to go to turn the opinions of the Ministry of Education on the evaluation of scientific research results into practical methods. The research and evaluation methods of focusing the quantity and lighting the quality, focusing the content and lighting the form have not been fundamentally reversed in colleges and universities. In recent years, some places have made progress in exploring the evaluation methods of scientific research results. For example, in August 2015, Guangdong Province issued the "Several Opinions on Further Reforming the Evaluation of Professional Titles of Scientific and Technological Personnel". This regulation achieves a breakthrough in the relationship between the number and quality of scientific research results. Where the first author or the first correspondent author publishes an article in a high-quality publication, professional title evaluation would no longer requires the number of the papers. It should increase the proportion of patent and scientific research achievements in professional title evaluation. If the teachers are awarded the China Patent Excellence Award, the Guangdong Inventor Award and the Guangdong Patent Gold Award, these prizes would be two papers instead. If the teachers (the top 3 inventors) are awarded one Guangdong Patent Excellence Award, this prize would be one paper instead. [5] From 2012,
Fudan University began to test the representative system of the title evaluation papers. And it would no longer simply use the commonly used SCI, SSCI, CSSCI and other citation data methods to judge the quality of the paper. These explorations have only opened a good start. The education department should continue to explore the evaluation system of scientific research results, create a good atmosphere for the research work of young teachers, encourage and support young teachers to concentrate on their research. The teachers should carefully promote the present disciplinary developments, the establishment of new disciplines and new research areas, and new technology development with quality products.

Thirdly, the college should solve the practical difficulties of young teachers in colleges and universities. Also, the college should build a social service platform for young teachers in colleges and universities. At present, the social services of young teachers in colleges and universities are not strong in combination with their own professional advantages. They are not only affected by their own economic conditions, but also related to the lack of platforms. To improve the quality of young teachers' social services and promote the organic integration of social services and career development, it is necessary to do a good job in two aspects. On the one hand, it should deepen the reform of the income distribution system in colleges and universities. The allocation of allowances and bonuses is appropriately inclined to young teachers. This would help young teachers solve practical problems in their lives, and reduce their economic worries when serving the society. And it would urge the teachers to give priority to their professional expertise. On the other hand, relevant departments should actively build social service platforms for young teachers and encourage young teachers to actively participate in social services. First, the colleges should establish a social practice base for young teachers to ensure that young teachers can participate in social practice activities frequently. The Beijing Municipal Education Commission's exploration of the social practice base for young teachers has taken the lead in the country. In 2012, the "Implementation Opinions on Organizing Young Teachers in Beijing to Conduct Social Practice Activities" was issued, which has built a social practice platform for young teachers in enterprises, government departments, communities, villages and other fields. The second is to select young teachers to work. It is a common practice in all provinces and cities to select outstanding young teachers to work in the municipal government departments and enterprises. On-the-job selection generally follows the principle of professional counterparts and expertise. The young teachers who are employed should actively participate in the relevant work of the units, make full use of the resources of the units and universities, and combine their own theories and professional advantages to help the units solve practical problems and promote the development of units. The third is to promote young teachers to participate in the project of production, education and research. The combination of production, study and research refers to the synergy and integration of production, education and scientific research in terms of resources and functional advantages, and realizes the 
effective docking of technological innovation in the top, middle and lower reaches. The combination of production, study and research helps young teachers understand the technological transformation of enterprises and product development. Also, with their own scientific research advantages, the teachers would provide rationalization suggestions for enterprises to optimize production. It also helps young teachers accumulate practical experience and promote the smooth development of their careers.

\section{CONCLUSION}

In short, the formation of professional confusion among young teachers in colleges and universities is a complex issue. It includes both social influences and factors of education departments and young teachers. To promote the young teachers of colleges and universities to get out of the predicament of professional development, it is necessary for the society, the education department, and the young teachers to work together and make a multi-pronged approach. Young teachers in colleges and universities gradually grow into "four haves" teachers. Among them, the ideal concept is the spiritual pillar of the career development of young teachers. The accuracy and firmness of ideals and beliefs largely determine the height of a person's professional development. Morality is the fundamental basis for the professional development of young teachers. The solid knowledge is an important guarantee for the career development of young teachers. The teachers must always be in a state of learning. They rigorously work hard, constantly enrich and perfect its own knowledge structure system. The heart of benevolence is the source of motivation for the career development of young teachers. The benevolence is not only a basic requirement for young teachers to carry out educational activities, but also a source of motivation for their career development. In the process of promoting students' healthy growth, young teachers have also developed and achieved a "win-win" situation in teaching and learning.

\section{REFERENCES}

[1] Xi Jinping Called on the Teachers of the Whole Country to be Good Teachers of the Party and the People While Visiting Beijing Normal University [N], People's Daily, 2014-09-10(1).200 习近平在北京师 范大学考察时号召全国广大教师做党和人民满意的好老师 [N], 人民日报，2014-09-10 (1).

[2] Luo Xu. "We Will not Talk about Innovation now" - Zhang Yaoxue, the President of Central South University, Talks about Comprehensive Reform [N]. Guangming Daily, 2014-08-24 (1). 罗 旭. “我们现在先不谈创新”一中南大学校长张尧学谈综合改革 [N].光明日报，2014-08-24（1）.

[3] Notice of Guangdong Provincial Department of Education on Doing a Good Job in the Application and Evaluation of Professional and Technical Qualifications of Teachers in Colleges and Universities in 2015

[EB/OL].http://www.gdhed.edu.cn/publicfiles/business/htmlfiles/gdjy t/ Gdjyt/tzgg/201508/491330.html. 广东省教育厅关于做好 2015 年 度高等学校教师专业技术资格申报和评审工作的通知 [EB/OL].http://www.gdhed.edu.cn/publicfiles/business/htmlfiles/gdjy t/ gdjyt/tzgg/201508/491330.html.

[4] Opinions of the Ministry of Education on Further Improving the Evaluation of Philosophy and Social Science Research in Higher Education

[EB/OL].
http://www.moe.edu.cn/publicfiles/business/htmlfiles/moe/A13_zcwj/ 201111/126301.html. 教育部关于进一步改进高等学校哲学社会 科学 研 究 评价的意见 [EB/OL] http://www.moe.edu.cn/publicfiles/business/htmlfiles/moe/A13_zcwj/ 201111/126301.html.

[5] Opinions of the Ministry of Human Resources and Social Security of Guangdong Province and the Department of Science and Technology of Guangdong Province on Further Reforming the Evaluation of Professional Titles of Scientific and Technological Personnel [EB/OL].http://www.gdhrss.gov.cn/publicfiles/business/htmlfiles/gdh rss/s59/201508/54375.html. 广东省人力资源和社会保障厅、广东 省科学技术厅关于进一步改革科技人员职称评价的若干意见 EB/OL].http://www.gdhrss.gov.cn/publicfiles/business/htmlfiles/gdhr ss/s59/201508/54375.html. 